\title{
Management of severe atopic dermatitis in adult patients
}

\author{
Postępowanie w ciężkim atopowym zapaleniu skóry u dorosłych
}

Aleksandra Kobusiewicz',2, Anna M. Zalewska-Janowska', Aleksandra Lesiak², Joanna Narbutt²

'Department of Psychodermatology, the Chair of Clinical Immunology and Rheumatology, the Medical University in Lodz, Poland 2Department of Dermatology, Paediatric Dermatology and Oncologic Dermatology, Medical University in Lodz, Poland

'Zakład Psychodermatologii, Katedra Immunologii Klinicznej i Reumatologii, Uniwersytet Medyczny w Łodzi, Polska ${ }^{2}$ Klinika Dermatologii, Dermatologii Dziecięcej i Onkologicznej, Uniwersytet Medyczny w Łodzi, Polska

\section{CORRESPONDING AUTHOR/} ADRES DO KORESPONDENCJI:

Aleksandra Kobusiewicz Zakład Psychodermatologii Katedra Immunologii Klinicznej i Reumatologii Uniwersytet Medyczny w Łodzi ul. Czechosłowacka 8/10 92-216 Łódź e-mail: kobusiewicz.aleksandra@ gmail.com

\begin{abstract}
Atopic dermatitis is a chronic recurrent inflammatory condition of the skin. It can coexist with other atopy-related disorders, e.g. bronchial asthma, allergic rhinitis or food allergy. Beacuse of its chronic course and concomitance of pruritus, atopic dermatitis considerably decreases the quality of life of patients and their family members. Management of atopic dermatitis mainly involves appropriate skin care and daily application of emollients, combined with topical anti-inflammatory treatment. It is essential to initiate systemic immunosuppressive therapy in moderate or severe atopic dermatitis. The aim of the study is to present current therapeutic options for atopic dermatitis in adults, with particular consideration given to the approved biological treatment. Dupilumab was included in the management algorithm as the first-line treatment in moderate or severe atopic dermatitis, unresponsive to topical therapy and in cases in which systemic treatment is contraindicated.
\end{abstract}

\section{STRESZCZENIE}

Atopowe zapalenie skóry to przewlekła, nawrotowa choroba zapalna skóry, która może współistnieć z innymi schorzeniami z kręgu atopii, takimi jak astma oskrzelowa, alergiczny nieżyt nosa oraz alergia pokarmowa. Ze względu na przewlekły przebieg choroby oraz współwystępowanie świądu obniżona jest istotnie jakość życia pacjentów i ich rodzin. Podstawą leczenia jest właściwa pielęgnacja skóry polegająca na codziennym stosowaniu emolientów w połączeniu z miejscowym leczeniem przeciwzapalnym. W atopowym zapaleniu skóry o umiarkowanym lub ciężkim przebiegu istotne jest włączenie immunosupresyjnego leczenia ogólnoustrojowego. Celem opracowania jest przedstawienie aktualnych opcji terapeutycznych w atopowym zapaleniu skóry u dorosłych, szczególnie zarejestrowanego leczenia biologicznego. Dupilumab został włączony do algorytmu postępowania jako leczenie pierwszego wyboru w umiarkowanej do ciężkiej postaci atopowego zapalenia skóry u dorosłych, gdy nie uzyskuje się odpowiedzi na leczenie miejscowe i gdy inne leczenie systemowe nie jest wskazane.

Key words: SCORAD, dupilumab, biological treatment, atopic dermatitis. Słowa kluczowe: SCORAD, dupilumab, leczenie biologiczne, atopowe zapalenie skóry. 


\section{INTRODUCTION}

Atopic dermatitis (AD) is one of the most common chronic inflammatory skin diseases in the world [1]. The disease affects both children (15-30\%) and adults $(2-10 \%)[2,3]$. An increase in the incidence of $\mathrm{AD}$ has been observed over the past few decades, especially in developed countries. It is also believed that the number of concomitant diseases associated with the allergic march, such as asthma, allergic rhinoconjunctivitis, food allergy, eosinophilic esophagitis is increasing [4]. Scientific research increasingly often show the association of severe forms of AD with cardiovascular diseases [5-7], lymphomas [8], neuropsychiatric conditions [9] probably associated with chronic inflammation, but definitive confirmation of the relationship between diseases requires long-term observation and meta-analyzes. For many years scientists have been linking severity and duration of the disease with psychological and neuropsychiatric problems, providing the foundation for a new theory of the psychiatric march in AD [10]. It was found that the itching associated with the disease significantly affects sleep leading to chronic fatigue during the day, inability to conduct everyday activities at school and work, irritability, attention deficit disorder (ADHD), which translates into deterioration of relationships with peers and family [11-14]. The chronic course of the disease and reduced quality of life can lead to anxiety disorders, depression and even suicidal thoughts $[10,15]$.

Many of these disorders and concomitant diseases can disappear completely or partially due to personalized treatment of AD depending on severity of symptoms, which emphasizes the importance of achieving adequate long-term disease control [16]. In severe cases, psychological support may be required. New biological drugs are an opportunity for patients who do not respond to existing topical and systemic treatments.

\section{THE ASSESSMENT OF SEVERITY OF THE DISEASE}

Diagnosis of the disease is still based on clinical criteria of Hanifin and Rajka formulated in 1980 and modified in later years [17, 18].

Assessment of the severity of the disease is important, to select the appropriate therapeutic option and to determine effectiveness of the treatment, both in everyday medical practice and in clinical trials. Currently, over 20 scales covering various aspects of the disease have been described. Of all available multiple validated scales, the established working group HOME (Harmonizing Outcome Measures for Eczema) recognized the SCORAD (Scoring Atopic Dermatitis Index) and EASI (Eczema Area Severity

\section{WPROWADZENIE}

Atopowe zapalenie skóry (AZS) jest jedną z najczęstszych przewlekłych chorób zapalnych skóry na świecie [1]. Dotyczy zarówno dzieci (15-30\%), jak i osób dorosłych (2-10\%) [2,3]. Obserwuje się wzrost częstości występowania AZS w czasie ostatnich kilku dekad, szczególnie w krajach rozwiniętych. Uważa się, że wzrasta również liczba chorób współistniejących związanych z marszem alergicznym, takich jak astma, alergiczne zapalenie błony śluzowej nosa i spojówek, alergia pokarmowa, eozynofilowe zapalenie przełyku [4]. Badania naukowe coraz częściej wykazują związek ciężkich postaci AZS z chorobami układu sercowo-naczyniowego [5-7], chłoniakami [8], chorobami neuropsychiatrycznymi [9], prawdopodobnie związanymi z przewlekłym stanem zapalnym, jednak ostateczne potwierdzenie tego związku wymaga długoletnich obserwacji oraz metaanaliz. Od wielu lat naukowcy wykazują powiązanie nasilenia i czasu trwania choroby z problemami psychicznymi i neuropsychiatrycznymi, co tworzy podwaliny nowej teorii marszu psychiatrycznego w AZS [10]. Stwierdzono, że związany z chorobą świąd znamiennie wpływa na zakłócenia snu prowadzące do przewlekłego zmęczenia w ciągu dnia, niezdolności do wykonywania codziennych czynności w szkole i pracy, drażliwości, zespołu deficytu uwagi (ADHD), co przekłada się na pogorszenie relacji z rówieśnikami i rodziną [11-14]. Przewlekły przebieg choroby oraz obniżona jakość życia mogą powodować zaburzenia lękowe, depresję, a nawet myśli samobójcze [10,15].

Wiele z tych zaburzeń oraz chorób współistniejących może ustępować całkowicie lub częściowo dzięki spersonalizowanemu leczeniu AZS w zależności od nasilenia objawów, co podkreśla znaczenie osiągnięcia długotrwałej kontroli choroby [16]. W przypadkach o ciężkim przebiegu klinicznym konieczne bywa wsparcie psychologiczne. Nowe leki biologiczne są szansą dla pacjentów, którzy nie odpowiadają na dotychczas dostępne leczenie miejscowe i ogólnoustrojowe.

\section{OCENA STOPNIA NASILENIA CHOROBY}

Rozpoznanie choroby nadal opiera się na sformułowanych w 1980 roku i zmodyfikowanych w późniejszych latach kryteriach klinicznych Hanifina i Rajki $[17,18]$.

Istotna jest ocena stopnia nasilenia choroby w celu wybrania odpowiedniej opcji terapeutycznej oraz określenia skuteczności leczenia, zarówno w codziennej praktyce lekarskiej, jak i w badaniach klinicznych. Dotychczas opisano ponad 20 skal uwzględniających różne aspekty choroby. Spośród wszystkich dostępnych, wielokrotnie zwalidowanych narzędzi grupa robocza HOME (Harmonising Outcome Measures for Eczema) uznała SCORAD (Scoring Atopic Dermatitis 
Index) scales as reliable tools for use in both clinical trials and in everyday clinical practice [19].

SCORAD is the most commonly used scale in AD in children and adults [20]. It is used to assess objective (extent and severity of skin lesions) and subjective symptoms (worsening of pruritus and sleep disorders). It is important to assess dryness of the non-affected skin, and to assess the remaining symptoms in the most representative places. AD is classified as benign if the score is less than 25 points, moderate for $25-50$ points and severe above 50 points [21]. SCORAD presents a high correlation with the overall assessment of the severity of the disease and has good reproducibility in children and adults (fig. 1).

EASI is the second most frequently used scale to assess the severity of AD in children and adults. It is a modified version of the PASI scale used in psoriasis. It takes into account the extent and severity of skin lesions without assessing any of the patient's subjective symptoms (pruritus, sleep disorders) $[22,23]$. This scale is more sensitive in relation to clinically significant changes assessed in specific areas of the body compared to the SCORAD scale, therefore it is used more often than SCORAD to assess the effectiveness of treatment, especially in clinical trials [24].

The 5-stage IGA (Investigators' Global Assessment) scale is often used to assess overall severity of $\mathrm{AD}$ and treatment effectiveness [25].

\section{MANAGEMENT}

The management of AD is comprehensive and depends on severity of the disease. It involves patient and family education, prevention, skin care, topical anti-inflammatory treatment, and systemic therapy. A novelty introduced in 2018 to the algorithm of treatment of AD in adults is the biological drug dupilumab, as the first-line drug for the treatment of severe form of AD in adults who do not respond to topical treatment and in whom systemic treatment is contraindicated [26]. Psychological support for the patient and his family is an inseparable element of the procedure. European recommendations for the management of AD in adults published in 2018 are presented in table 1.

\section{EDUCATION}

The patient should be educated immediately after the diagnosis, to understand the essence and course of the disease, and thus consciously take responsibility in the treatment of the chronic disease [27]. The educational process should prepare the patient to recognize the severity of AD symptoms so that he/she can quickly implement a basic topical treatment [28].
Index) i EASI (Eczema Area Severity Index) za wiarygodne skale do użytku zarówno w badaniach klinicznych, jak i w codziennej praktyce [19].

SCORAD jest najczęściej stosowaną skalą w AZS $\mathrm{u}$ dzieci i dorosłych [20]. Za jej pomocą oceniane są objawy obiektywne (rozległość zmian skórnych i ich nasilenie) oraz subiektywne (nasilenie świądu i zaburzenia snu). Istotne jest, aby oceniać suchość skóry w okolicy niezajętej przez chorobę, a pozostałe objawy w miejscach najbardziej reprezentatywnych. AZS klasyfikowane jest jako łagodne w przypadku uzyskania mniej niż 25 pkt, umiarkowane w przypadku 25-50 pkt i ciężkie powyżej 50 pkt [21]. SCORAD wykazuje wysoką korelację z ogólną oceną nasilenia choroby oraz cechuje się dobrą powtarzalnością u dzieci i dorosłych (ryc. 1).

EASI jest drugą co do częstości stosowania skalą oceniającą nasilenie AZS u dzieci i dorosłych. Jest zmodyfikowaną wersją skali PASI wykorzystywanej w łuszczycy. Uwzględnia rozległość i nasilenie zmian skórnych bez oceny objawów subiektywnych (świąd, zaburzenia snu) $[22,23]$. Skala ta jest bardziej czuła na klinicznie istotne zmiany oceniane $\mathrm{w}$ określonych obszarach ciała w porównaniu ze skalą SCORAD, w związku z tym częściej niż SCORAD jest używana do oceny skuteczności leczenia, zwłaszcza w badaniach klinicznych [24].

Do ogólnej oceny nasilenia AZS i skuteczności leczenia często używana jest 5-stopniowa skala IGA (Investigators' Global Assessment) [25].

\section{POSTĘPOWANIE}

Postępowanie w AZS jest kompleksowe i zależy od stopnia nasilenia choroby. Obejmuje edukację pacjenta i jego rodziny, profilaktykę, pielęgnację skóry, miejscowe leczenie przeciwzapalne oraz terapię ogólnoustrojową. Nowością w leczeniu AZS u dorosłych jest włączenie w 2018 r. do algorytmu postępowania leku biologicznego - dupilumabu - jako leku pierwszego wyboru w ciężkiej postaci AZS u dorosłych, którzy nie reagują na leczenie miejscowe i u których leczenie systemowe jest niewskazane [26]. Nieodłącznym elementem postępowania jest wsparcie psychologiczne pacjenta i jego rodziny. Europejskie rekomendacje postępowania w AZS u dorosłych opublikowane w 2018 r. zostały przedstawione w tabeli 1 .

\section{EDUKACJA}

Pacjent powinien być edukowany natychmiast po postawieniu diagnozy, aby zrozumiał istotę oraz przebieg choroby, a także świadomie przejął odpowiedzialność za przewlekłe leczenie [27]. Proces edukacyjny powinien przygotowywać pacjenta do rozpoznawania nasilenia objawów AZS, aby mógł odpowiednio szybko wdrożyć podstawowe lecze- 
SCORAD - Scoring Atopic Dermatitis Index
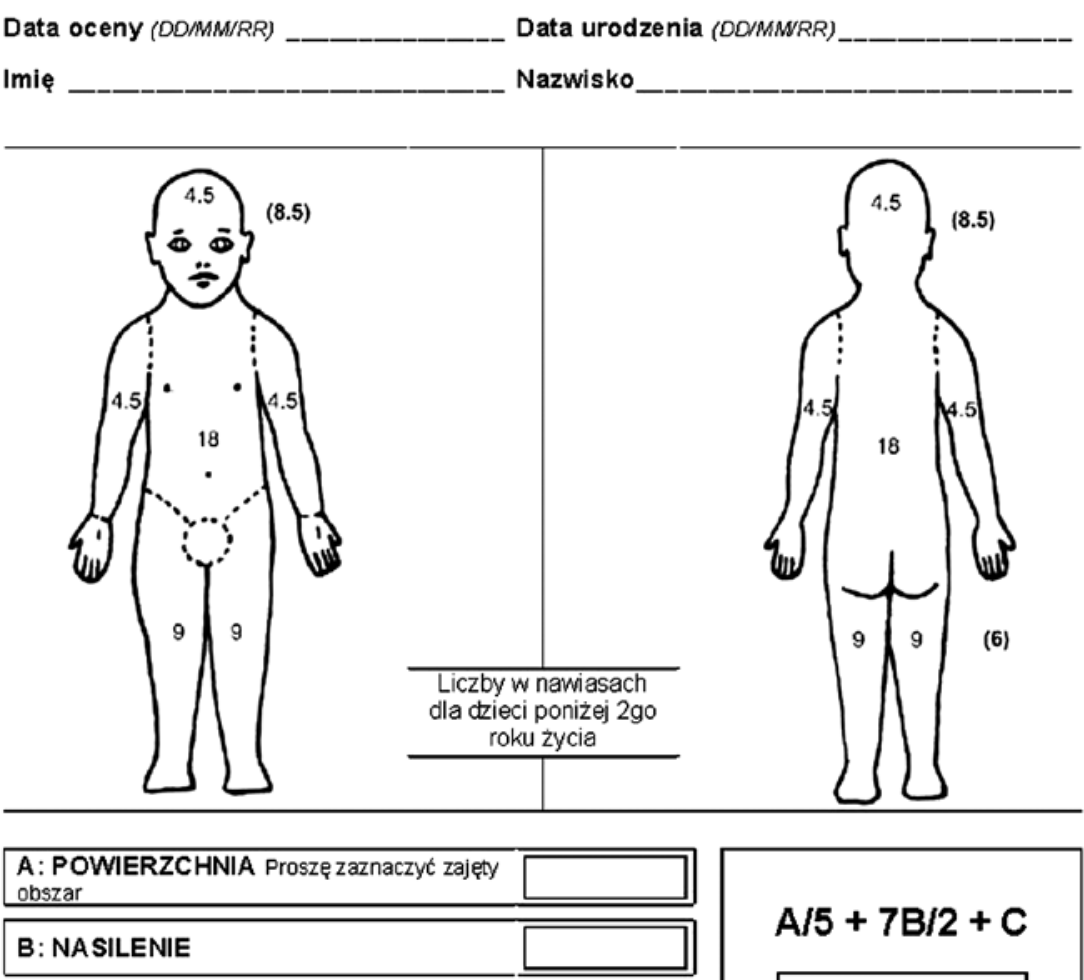

C: OBJAWY SUBIEKTYWNE
SWMAQ + BEZSENNOŚC

$\mathrm{A} / 5+7 \mathrm{~B} / 2+\mathrm{C}$

SWAD + BEZSENNOSC

\begin{tabular}{|l|l|}
\hline Kryteria & Nasilenie \\
\hline Rumień & \\
\hline Obrzęk/Grudki & \\
\hline Sączenie/Strupy & \\
\hline Przeczosy & \\
\hline Lichenizacja & \\
\hline Suchość skóry & \\
\hline
\end{tabular}

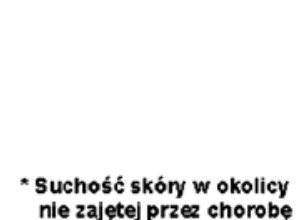

\begin{tabular}{|l|}
\hline PUNKTACJA NASILENIA \\
\hline ( reprezentatywna powierzchnia ) \\
$0=$ brak \\
$1=$ lekkie \\
$2=$ średnie \\
$3=$ nasilone
\end{tabular}

Wizualna skala analogowa (średnia dla ostatnich 3 dni lub nocy)

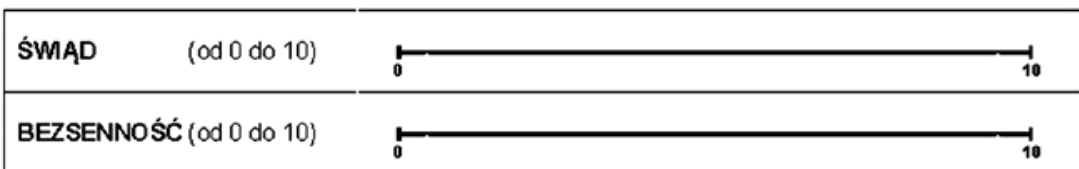

Podpis i pieczęć lekarza badającego

Figure I. Atopic dermatitis severity assessment scale SCORAD

Rycina I. Skala oceny nasilenia atopowego zapalenia skóry SCORAD

The patient's proper understanding of the importance of using emollients in skin care and the need for antiinflammatory treatment with local glucocorticosteroids (GCS) and calcineurin inhibitors is aimed at self-control of exacerbations, maintaining long-term remission through proactive therapy, and preventing steroidophobia. nie miejscowe [28]. Właściwe zrozumienie przez pacjenta znaczenia pielęgnacji skóry emolientami oraz potrzeby leczenia przeciwzapalnego miejscowymi glikokortykosteroidami (GKS) i inhibitorami kalcyneuryny pozwala na samodzielną kontrolę zaostrzeń, utrzymanie długoterminowej remisji poprzez terapię proaktywną oraz przeciwdziała steroidofobii. 
Table I. European treatment recommendation of atopic dermatitis in adults

Tabela I. Europejskie rekomendacje dotyczące leczenia atopowego zapalenia skóry u dorosłych

\begin{tabular}{|c|c|}
\hline $\begin{array}{l}\text { Severe AD/Ciężkie AZS } \\
\text { SCORAD }>50 / \\
\text { SCORAD }>50\end{array}$ & $\begin{array}{l}\text { Hospitalization/Hospitalizacja } \\
\text { Cyclosporin dupilumab, phototherapy (PUVA)/Cyklosporyna, dupilumab, fototerapia (PUVA) } \\
\text { Short courses of systemic glucocorticosteroids/Krótkie kursy glikokortykosteroidów ogólnie } \\
\text { Off-label treatment: methotrexate, azathioprine, mycophenolate mofetil/Leczenie off-label: metotreksat, } \\
\text { azatiopryna, mykofenolan mofetylu } \\
\text { Alitretinoin - for treatment of severe chronic eruptions on hands, resistant to treatment with potent } \\
\text { glucocorticosteroids, not available in Poland/Alitretynoina - do stosowania w ciężkim, przewlekłym } \\
\text { wyprysku rąk opornym na leczenie silnymi glikokortykosteroidami, niedostępna w Polsce } \\
\text { Periodical intensification of the basic treatment e.g. emollients, topical glucocorticosteroids applied as a wet } \\
\text { dressing/Okresowa intensyfikacja leczenia podstawowego, np. emolienty, miejscowo glikokortykosteroidy } \\
\text { pod wilgotnym opatrunkiem } \\
\text { Psychological care/Opieka psychologiczna }\end{array}$ \\
\hline $\begin{array}{l}\text { Moderate AD/ } \\
\text { Umiarkowane AZS } \\
\text { SCORAD 25-50/ } \\
\text { SCORAD 25-50 }\end{array}$ & $\begin{array}{l}\text { Topical glucocorticosteroids class II or III as the proactive therapy/Miejscowo glikokortykosteroidy II lub } \\
\text { III klasy w terapii proaktywnej } \\
\text { Topical tacrolimus as the proactive therapy/Miejscowo takrolimus w terapii proaktywnej } \\
\text { Phototherapy UVB } 3 \text { I I nm, UVA I/Fototerapia UVB } 3 \text { I I nm, UVAI } \\
\text { Periodical intensification of the basic treatment e.g. emollients, topical glucocorticosteroids applied as } \\
\text { a wet dressing/Okresowa intensyfikacja leczenia podstawowego, np. miejscowo glikokortykosteroidy pod } \\
\text { wilgotnym opatrunkiem } \\
\text { Psychological care, balneotherapy/Opieka psychologiczna, balneoterapia }\end{array}$ \\
\hline $\begin{array}{l}\text { Mild AD/Lagodne AZS } \\
\text { SCORAD }<25 / \\
\text { SCORAD }<25\end{array}$ & $\begin{array}{l}\text { Topical glucocorticosteroids class II/Miejscowo glikokortykosteroidy II klasy } \\
\text { Topical calcineurin inhibitors/Miejscowo inhibitory kalcyneuryny } \\
\text { Application of silver preparations/Stosowanie preparatów ze srebrem }\end{array}$ \\
\hline $\begin{array}{l}\text { Basic treatment/Leczenie } \\
\text { podstawowe }\end{array}$ & $\begin{array}{l}\text { Education programs, schools of atopy/Programy edukacyjne, szkoły atopii } \\
\text { Emollient therapy 2-3 times a day, dermo-cosmetics for skin clearance/Terapia emolientowa 2-3 razy } \\
\text { na dobę, dermokosmetyki do mycia skóry } \\
\text { Avoiding irritating factors (e.g. rough fabrics) and exacerbating factors (sweating, stress)/Unikanie } \\
\text { czynników drażniących (np. szorstkie tkaniny) i zaostrzających (spocenie, stres) } \\
\text { Anti-microbial treatment of bacterial superinfections/Leczenie przeciwdrobnoustrojowe nadkażeń } \\
\text { bakteryjnych }\end{array}$ \\
\hline
\end{tabular}

\section{SKIN CARE - EMOLLIENTS}

In recent years, modern emollients with medicinal properties have appeared in the market, which contain active ingredients such as saponins, flavonoids and riboflavins or bacterial lysates from Aquaphilus dolomiae or Vitreoscilla filiformis. These preparations reduce skin inflammation and have a positive effect on the skin microbiome of patients with AD [29-31].

The estimated weekly demand for emollients in an adult is about $500 \mathrm{~g}$. Regular and long-term use of emollients reduces the necessity and amount of topical GCS [32]. It should be remembered that emollients applied directly to inflamed skin may be poorly tolerated, therefore, in such situations, it is recommended to apply topical GCS or calcineurin inhibitors (CI) treatment in combination with emollients [33].

\section{TOPICAL ANTI-INFLAMMATORY TREATMENT}

Basic topical drugs used in the treatment of $\mathrm{AD}$ include class II and III topical GCS and CI - pimecrolimus $1 \%$ cream and tacrolimus $0.03 \%$ and $0.1 \%$ cream. Topical medications should always be applied to moisturized skin, especially when they are

\section{PIELĘGNACJA SKÓRY - EMOLIENTY}

Ostatnio pojawiły się nowoczesne emolienty o właściwościach leczniczych, które zawierają aktywne składniki, takie jak saponiny, flawonoidy i ryboflawiny lub lizaty bakteryjne z Aquaphilus dolomiae lub Vitreoscilla filiformis. Preparaty te redukują stan zapalny skóry oraz pozytywnie oddziałują na mikrobiom skóry pacjentów z AZS [29-31].

Szacunkowo w skali tygodnia zapotrzebowanie na emolienty u dorosłej osoby wynosi ok. 500 g. Regularne i długotrwałe stosowanie emolientów zmniejsza konieczność stosowania miejscowych GKS i ich ilość [32]. Należy pamiętać, że aplikowanie emolientów bezpośrednio na stan zapalny może być źle tolerowane, dlatego w takich sytuacjach zaleca się stosowanie najpierw miejscowych GKS lub inhibitorów kalcyneuryny (IK) w połączeniu z emolientami [33].

\section{MIEJSCOWE LECZENIE PRZECIWZAPALNE}

Do podstawowych leków miejscowych stosowanych w AZS należą miejscowe GKS II i III klasy oraz miejscowe IK - pimekrolimus w postaci kremu $1 \%$ oraz takrolimus w postaci maści 0,03\% i 0,1\%. Leki miejscowe, zwłaszcza w formie maści, należy zawsze stosować na 
used in the form of ointment. Patients with acute, exudative lesions and erosions may not tolerate topical anti-inflammatory drugs. In those situations, the use of wet dressings with diluted GCS for 3 to 14 days allows a relatively safe intervention for severe, exudative and/or refractory AD [34]. Adrenal suppression may be an adverse effect of wet topical GCS dressings therefore morning cortisol monitoring is recommended. The frequency of wet dressings or occlusive treatment per day depends on severity of skin lesions. Most often, these methods are used once a day to achieve a rapid reduction of efflorescence. After skin lesions have resolved, it is recommended to use proactive therapy to extend the remission period. The length of treatment depends on severity of the disease. The use of topical GCS in proactive therapy should not last more than 16 weeks, and of tacrolimus - no longer than 52 weeks [35, 36]. Mean monthly dose of topical GCS used in adults ranges from $60 \mathrm{~g}$ to $90 \mathrm{~g}[35,36]$.

Since 2016, a new group of anti-inflammatory drugs has been approved - phosphodiesterase 4 inhibitors. One of them is crisaborol [37]. It is used in the United States in patients with mild to moderate AD, over 2 years of age. This medicine is not yet available in Europe.

\section{TOPICAL AND GENERAL ANTIMICROBIAL TREATMENT}

The skin of patients suffering from $\mathrm{AD}$ is in over $90 \%$ of cases colonized by Staphylococcus aureus. This is often associated with a more severe course of AD exacerbations. Due to the increasing antibiotic resistance, it is recommended to limit the chronic use of topical antibiotics. Studies show that anti-inflammatory treatment with topical GCS, CI and phototherapy reduce skin colonization with Staphylococcus aureus in AD, which favors reduced use of topical antibiotics [38].

Oral antibiotics from the cephalosporin group should only be used in cases of acute AD with clinical signs of bacterial infection.

\section{SYSTEMIC IMMUNOSUPPRESSIVE TREATMENT}

The addition of phototherapy, cyclosporin A (CsA), dupilumab or off label methotrexate (MTX), azathioprine (AZA) or mycophenolate mofetil (MMF) should be considered in patients with AD who did not improve with topical anti-inflammatory therapy. The use of systemic GCS should be limited to shortterm (up to 1 week) treatment of exacerbations in severe $A D$. nawilżoną skórę. Pacjenci z ostrymi, sączącymi zmianami oraz z nadżerkami mogą nie tolerować miejscowych leków przeciwzapalnych. W takich sytuacjach stosowanie mokrych opatrunków z rozcieńczonymi GKS przez 3-14 dni pozwala na relatywnie bezpieczne leczenie interwencyjne ciężkiego, wysiękowego i/lub opornego na leczenie AZS [34]. Działaniem niepożądanym mokrych opatrunków z miejscowymi GKS może być supresja nadnerczy, dlatego zaleca się poranne monitorowanie kortyzolu. Częstość aplikowania mokrych opatrunków lub leczenia okluzyjnego zależy od nasilenia zmian skórnych. Najczęściej stosuje się te metody raz na dobę, co pozwala uzyskać szybką redukcję wykwitów. Po ustąpieniu zmian skórnych zalecane jest prowadzenie terapii proaktywnej w celu wydłużenia okresu remisji. Długość leczenia zależy od nasilenia choroby. Miejscowe GKS powinny być stosowane w terapii proaktywnej nie dłużej niż 16 tygodni, a takrolimus nie dłużej niż 52 tygodnie $[35,36]$. Miesięczna średnia dawka miejscowych GKS dla dorosłych wynosi od $60 \mathrm{~g}$ do $90 \mathrm{~g}[35,36]$.

Od 2016 r. dopuszczona jest nowa grupa leków przeciwzapalnych - inhibitory fosfodiesterazy 4, których przedstawicielem jest kryzaborol [37]. Jest on stosowany w Stanach Zjednoczonych u pacjentów powyżej 2. roku życia z łagodną do umiarkowanej postaci AZS. Lek ten nie jest na razie dostępny w Europie.

\section{MIEJSCOWE I OGÓLNE LECZENIE PRZECIWDROBNOUSTROJOWE}

Skóra chorych na AZS w ponad 90\% przypadków jest skolonizowana przez Staphylococcus aureus, co często wiąże się z cięższym przebiegiem zaostrzeń choroby. Ze względu na narastającą antybiotykooporność zaleca się ograniczenie przewlekłego stosowania antybiotyków miejscowych. Badania dowodzą, że leczenie przeciwzapalne miejscowymi GKS i IK oraz fototerapia w AZS zmniejszają kolonizację skóry gronkowcem złocistym, co sprzyja ograniczeniu stosowania miejscowo antybiotyków [38].

Antybiotyki doustne z grupy cefalosporyn powinny być stosowane wyłącznie w przypadkach zaostrzonego AZS z klinicznymi objawami zakażenia bakteryjnego.

\section{OGÓLNOUSTROJOWE LECZENIE IMMUNOSUPRESYJNE}

U pacjentów z AZS, u których miejscowa terapia przeciwzapalna nie przyniosła poprawy, należy rozważyć dołączenie fototerapii, cyklosporyny A (CsA), dupilumabu lub leczenie off label metotreksatem (MTX), azatiopryną (AZA) lub mykofenolanem mofetylu (MMF). Stosowanie GKS ogólnie powinno być ograniczone do krótkoterminowego (do 1 tygodnia) leczenia zaostrzeń w ciężkiej postaci AZS. 


\section{PHOTOTHERAPY}

Phototherapy UVA1 (340-400 nm), UVB-BB (290$320 \mathrm{~nm})$ and UVB-NB $(311-313 \mathrm{~nm})$ is the secondline treatment in patients with recurrent and chronic forms of $\mathrm{AD}$, moderate to severe (SCORAD > 25), associated with intense pruritus and lichenization. It is not indicated during the exacerbation phase (except UVA1) and in patients who experience worsening of lesions after exposure to sunlight. Considering the safe and effective treatment profile, narrow beam UVB-NB therapy is the most often used as three irradiations a week with the initial dose depending on the skin phototype. The use of phototherapy in combination with topical anti-inflammatory treatment with GCS and the appropriate emollient treatment reduces the recurrence and allows reduction of the amount and potency of the topical GCS used. Phototherapy should be used with caution. When $95 \%$ improvement is achieved, maintenance therapy is recommended.

\section{CYCLOSPORIN A}

Cyclosporin A (CsA) is recommended as the firstline treatment for patients with severe chronic $\mathrm{AD}$ (SCORAD > 50) who require systemic therapy. The recommended initial dose is $4-5 \mathrm{mg} / \mathrm{kg}$ b.w./ day in two divided doses. After improvement, the CsA dose should be down-titrated by $0.5-1.0 \mathrm{mg} / \mathrm{kg}$ b.w./day every 2 weeks, to the minimum dose maintaining the therapeutic effect $(2.5-3 \mathrm{mg} / \mathrm{kg}$ b.w./ day) [39]. The drug may be administered as a continuous long-term therapy up to a maximum of 2 years, in cycles lasting on average 12-16 weeks, or as an intermittent, so-called 'weekend' therapy, twice a week at the appropriately selected dose [40]. The risk of adverse effects increases with the use of the drug at a dose above $5 \mathrm{mg} / \mathrm{kg}$ b.w./day, especially with persistently elevated creatinine values, as well as in the elderly patients. Permanent kidney damage (tubulopathy, vasculopathy) may occur in people who have been taking CsA continuously for more than 2 years.

\section{OFF-LABEL SYSTEMIC TREATMENT}

Methotrexate, AZA and MMF can be used off label in adults with severe $\mathrm{AD}$ resistant to other therapies [41].

Currently, MTX is recommended for the treatment of $\mathrm{AD}$ in adults at the initial dose of 5-15 mg/week, with up-titration to the minimum dose allowing control of the disease $(15-25 \mathrm{mg}$ / week). The treatment is usually well tolerated, but it is important to remember that there may be serious adverse effects. AZA is very effective in the treatment of $A D$, however, due to its mechanism of action, the full therapeutic effect

\section{FOTOTERAPIA}

Fototerapia UVA1 (340-400 nm), UVB-BB (290$320 \mathrm{~nm}$ ) oraz UVB-NB (311-313 nm) jest leczeniem drugiego wyboru u pacjentów z nawrotową i przewlekłą postacią AZS o umiarkowanym lub ciężkim przebiegu (SCORAD > 25) związaną z intensywnym świądem oraz lichenizacją. Nie jest wskazana w fazie zaostrzenia ( $\mathrm{z}$ wyjątkiem UVA1) oraz u pacjentów, u których następuje pogorszenie zmian po ekspozycji na promienie słoneczne. Ze względu na profil bezpieczeństwa i skuteczności najczęściej wykorzystywana jest terapia wąską wiązką promieniowania UVB-NB w schemacie trzech naświetlań $\mathrm{w}$ tygodniu, z dawką inicjującą zależną od fototypu skóry. Stosowanie fototerapii w połączeniu z miejscowym leczeniem przeciwzapalnym GKS oraz prawidłową aplikacją emolientów wpływa na redukcję nawrotów oraz zmniejszenie ilości i siły stosowanych miejscowo GKS. Podczas fototerapii należy zachować ostrożność w stosowaniu miejscowych IK. Po uzyskaniu 95-procentowej poprawy zaleca się stosowanie terapii podtrzymującej.

\section{CYKLOSPORYNA A}

Cyklosporyna A (CsA) jest rekomendowana jako lek pierwszego wyboru w leczeniu pacjentów z AZS o ciężkim, przewlekłym przebiegu (SCORAD > 50), którzy wymagają leczenia ogólnego. Zalecana początkowa dawka leku wynosi 4-5 mg/kg masy należnej/dobę w dwóch dawkach podzielonych. Po uzyskaniu poprawy wskazana jest redukcja dawki CsA o 0,5-1,0 mg/kg m.n./dobę co 2 tygodnie do minimalnej dawki podtrzymującej efekt terapeutyczny 2,5-3 mg/kg m.n./dobę [39]. Lek można podawać długoterminowo w terapii ciągłej, maksymalnie do 2 lat, w cyklach trwających średnio 12-16 tygodni lub w terapii przerywanej, tzw. weekendowej, 2 razy w tygodniu w odpowiednio dobranej dawce [40]. Ryzyko wystąpienia działań niepożądanych wzrasta przy stosowaniu dawki powyżej $5 \mathrm{mg} / \mathrm{kg}$ m.n./dobę, zwłaszcza przy utrzymujących się podwyższonych stężeniach kreatyniny, a także u osób starszych. U osób przyjmujących CsA w sposób ciągły przez ponad 2 lata może dojść do trwałego uszkodzenia nerek (tubulopatia, waskulopatia).

\section{LECZENIE OGÓLNE POZA WSKAZANIAMI REJESTRACYJNYMI}

Metotreksat, AZA i MMF mogą być stosowane poza wskazaniami rejestracyjnymi u dorosłych pacjentów z ciężką postacią AZS oporną na inne metody terapii [41].

Obecnie zaleca się MTX w leczeniu AZS u dorosłych w dawkach początkowo 5-15 mg tygodniowo, zwiększanych do minimalnej dawki kontrolującej chorobę - 15-25 mg tygodniowo. Leczenie jest zwykle dobrze 
is achieved only after 12 weeks. It is recommended to start treatment with AZA at the dose of $50 \mathrm{mg} /$ day and to continue it at the dose of $1-3 \mathrm{mg} / \mathrm{kg} /$ day [26]. Prior to initiation of the treatment, thiopurine methyltransferase (TPMT) levels should be measured, as myelosuppression may occur in individuals with congenital deficiency. Monitoring of liver function and blood cell counts is necessary during the treatment with MTX and AZA. MMF efficacy is comparable to that of CsA in the treatment of AD [42]. The treatment starts at the dose of 1-2 g/day. It should be remembered that MTX and MMF are teratogenic and should not be used during pregnancy. CsA is American Food and Drug Administration (FDA) category C.

\section{DUPILUMAB}

Dupilumab is the only biological drug that has undergone the phase III clinical trial in AD (SOLO1, SOLO2, LIBERTY AD CHRONOS, LIBERTY AD CAFE) [43-45]. It was approved in 2017 by FDA and European Medicines Agency (EMA) as the first-line treatment in moderate to severe AD in adults not responding to topical treatment and when other systemic treatment is not indicated $[26,46]$.

Dupilumab is a human monoclonal antibody blocking the $\alpha$ subunit common to the interleukin- 4 and interleukin-13 receptor. Its administration results in inhibition of the JAK-STAT pathway involved in the pathogenesis of AD [47]. The first dupilumab studies confirming its efficacy were conducted in adult patients with allergic asthma and in patients with elevated eosinophil count, and then continued in moderate to severe $\mathrm{AD}[48,49]$. In randomized, double-blind, placebo-controlled, multi-center studies, SOLO1 and SOLO2, patients received $300 \mathrm{mg}$ dupilumab or placebo every 2 weeks or weekly for 16 weeks [43]. In the LIBERTY AD CHRONOS study, patients used topical GCS or CI in addition to dupilumab at the dose of $300 \mathrm{mg}$ or placebo, every 2 weeks or weekly. They were treated for 52 weeks [44]. These studies were conducted on a group of 2,119 patients. In the SOLO 1, SOLO 2 and CHRONO studies, a statistically significantly higher percentage of patients randomly assigned to the dupilumab group achieved an IGA response of 0 or 1 , a $75 \%$ improvement on the EASI scale, and an improvement of $\geq 4$ points on the NRS scale compared to placebo as compared to the baseline. In addition to reduction of pruritus, the study authors demonstrated the effectiveness of dupilumab in reduction of sleep disorders and found an improvement in mental health and quality of life after the second week of the therapy with the drug. All results obtained so far for dupilumab indicate its good tolerability, high safety profile and lack of dose dependent toxicity. The adverse effect profile of du- tolerowane, ale należy pamiętać o możliwości wystąpienia poważnych działań niepożądanych. AZA jest bardzo skuteczna w leczeniu AZS, jednak ze względu na mechanizm działania pełny efekt terapeutyczny osiągany jest dopiero po 12 tygodniach. Zaleca się rozpoczęcie leczenia AZA od dawki $50 \mathrm{mg} /$ dobę i kontynuowanie w dawce 1-3 mg/kg m.c./dobę [26]. Przed rozpoczęciem leczenia powinno się oznaczyć aktywność metylotransferazy tiopurynowej (TPMT), gdyż u osób z jej wrodzonym niedoborem może dojść do mielosupresji. W trakcie leczenia MTX oraz AZA konieczne jest monitorowanie czynności wątroby i morfologii krwi. MMF ma udowodnioną skuteczność w leczeniu AZS, porównywalną z CsA [42]. Leczenie rozpoczyna się od dawki 1-2 g/dobę. Należy pamiętać, że MTX oraz MMF są teratogenne i nie powinny być stosowane $\mathrm{w}$ trakcie ciąży. CsA ma kategorię C według amerykańskiej Agencji Żywności i Leków (FDA).

\section{DUPILUMAB}

Dupilumab jest jedynym lekiem biologicznym, który przeszedł III fazę badań w AZS (SOLO1, SOLO2, LIBERTY AD CHRONOS, LIBERTY AD CAFE) [43-45]. Został zatwierdzony w 2017 r. przez FDA oraz Europejską Agencję Leków (EMA) jako leczenie pierwszego wyboru w umiarkowanej do ciężkiej postaci AZS u dorosłych, gdy nie uzyskuje się odpowiedzi na leczenie miejscowe i gdy inne leczenie ogólne nie jest wskazane [26, 46].

Dupilumab jest ludzkim przeciwciałem monoklonalnym blokującym podjednostkę $\alpha$ wspólną dla receptora interleukiny 4 i interleukiny 13. Jego podanie skutkuje hamowaniem ścieżki JAK-STAT biorącej udział w patogenezie AZS [47]. Pierwsze badania z zastosowaniem dupilumabu potwierdzające jego skuteczność zostały przeprowadzane $\mathrm{u}$ dorosłych pacjentów $\mathrm{z}$ astmą alergiczną oraz z podwyższonym poziomem eozynofilów, a następnie kontynuowane w AZS o umiarkowanym lub ciężkim przebiegu [48, 49]. W wieloośrodkowych badaniach $\mathrm{z}$ randomizacją prowadzonych metodą podwójnie ślepej próby, kontrolowanych placebo SOLO1 i SOLO2 - pacjenci otrzymywali 300 mg dupilumabu lub placebo co 2 tygodnie lub co tydzień przez 16 tygodni [43]. W badaniach LIBERTY AD CHRONOS pacjenci poza dupilumabem $\mathrm{w}$ dawce $300 \mathrm{mg}$ lub placebo co 2 tygodnie lub co tydzień stosowali jednocześnie miejscowe GKS lub IK. Leczenie trwało 52 tygodnie [44]. Badania te przeprowadzono w grupie 2119 pacjentów. W badaniach SOLO 1, SOLO 2 i CHRONOS u statystycznie istotnie większego odsetka pacjentów przydzielonych losowo do grupy otrzymującej dupilumab uzyskano odpowiedź IGA 0 lub 1, 75-procentową poprawę w skali EASI oraz poprawę o $\geq 4$ pkt oceny świądu wg skali NRS w porównaniu z placebo po zakończeniu badań w stosunku do stanu wyjściowego. 
pilumab was found to be favorable, compared to the available systemic therapy. AD patients treated with dupilumab did not show any systemic adverse effects in clinical trials. The most commonly observed adverse reaction was a local reaction following subcutaneous administration of the drug [50]. In addition, conjunctivitis has often been observed and should be monitored and treated by ophthalmologists [51, 52]. Adverse effects in the form of pharyngitis, headache, upper respiratory tract infections occurred sporadically. Studies published to date have shown that up to $70 \%$ of patients with AD treated with dupilumab achieved a significant improvement in EASI 75 or higher [53]. It took about 4 weeks to achieve full clinical control and in majority of patients the response was maintained for at least a year of continuous treatment.

The recommended initial dose of dupilumab in adults is $600 \mathrm{mg}$ in form of two injections of $300 \mathrm{mg}$, followed by $300 \mathrm{mg}$ every 2 weeks, administered subcutaneously. Dupilumab should be combined with regular emollients and may be combined with topical GCS or CI as needed, however their application should be limited to affected sites only [26]. If a dose of the biological drug is missed, it should be administered as soon as possible.

Studies on the use of dupilumab in children and adolescents with severe AD published so far indicate positive effects of the off label treatment with the drug [54]. Currently dupilumab has been registered in the USA for the use in children and adolescents between 6 and 17 years of age suffering from AD. For patients weighing $60 \mathrm{~kg}$ or more, the adult dosage regimen is used. In contrast, for patients weighing from $30 \mathrm{~kg}$ to $60 \mathrm{~kg}$, the starting dose is $400 \mathrm{mg}$ as two injections of $200 \mathrm{mg}$, followed by $200 \mathrm{mg}$ every 2 weeks, administered subcutaneously. For patients weighing between $15 \mathrm{~kg}$ and $30 \mathrm{~kg}$, an initial dose of $600 \mathrm{mg}$ as two $300 \mathrm{mg}$ injections is recommended, followed by $300 \mathrm{mg}$ every 4 weeks. In children from 6 months to 6 years of age with AD, the phase II and III clinical trials of Liberty AD PRESCHOOL (NCT03346434) are ongoing.

\section{CONCLUSIONS}

Emollients, topical GCS and CI as the proactive therapy are the basic treatment of AD. In cases not responding to standard topical treatment, the addition of phototherapy and CsA should be considered. In patients with severe $\mathrm{AD}$ who do not respond to topical therapy and in whom systemic treatment is not indicated, dupilumab is the first biological drug approved for AD treatment.

The role of biological treatment in effective and modern AD therapy is more and more important.
Autorzy badań poza redukcją świądu wykazali skuteczność dupilumabu w zmniejszaniu zaburzeń snu oraz stwierdzili poprawę zdrowia psychicznego i jakości życia już po 2 tygodniach stosowania leku. Wszystkie dotychczas uzyskane wyniki badań nad dupilumabem wskazują na jego dobrą tolerancję, wysokie bezpieczeństwo oraz brak toksyczności zależnej od dawki. Profil działań niepożądanych dupilumabu okazał się korzystny w porównaniu $\mathrm{z}$ dostępnym leczeniem ogólnym. Pacjenci z AZS leczeni dupilumabem nie wykazywali ogólnoustrojowych działań niepożądanych w badaniach klinicznych. Najczęściej obserwowanym objawem niepożądanym był miejscowy odczyn po podskórnym podaniu leku [50]. Ponadto często stwierdzano zapalenie spojówek, które powinno być kontrolowane i leczone przez okulistę $[51,52]$. Objawy niepożądane w postaci zapalenia błony śluzowej i gardła, bólu głowy oraz zakażeń górnych dróg oddechowych występowały sporadycznie. Wyniki dotychczas opublikowanych badań wykazały, że aż do 70\% pacjentów z AZS leczonych dupilumabem uzyskało wyraźną poprawę, EASI 75 lub wyższą [53]. Osiągnięcie pełnej kontroli klinicznej trwało ok. 4 tygodni, a odpowiedź utrzymywała się przez co najmniej rok ciągłego leczenia u większości pacjentów.

Zaleca się stosowanie dupilumabu u dorosłych w dawce początkowej $600 \mathrm{mg}$ w dwóch wstrzyknięciach po $300 \mathrm{mg}$, a następnie $300 \mathrm{mg}$ co 2 tygodnie, podawane podskórnie. Terapię dupilumabem należy łączyć z regularnym używaniem emolientów. W razie potrzeby można jednocześnie stosować miejscowe GKS lub IK, jednak ich aplikacja powinna być ograniczona wyłącznie do miejsc objętych zmianami [26]. W przypadku pominięcia dawki leku biologicznego należy podać ją jak najszybciej.

Opublikowane dotychczas badania dotyczące stosowania dupilumabu u dzieci i młodzieży z ciężką postacią AZS wskazują na pozytywne efekty leczenia off label tym lekiem [54]. Obecnie dupilumab został zarejestrowany w USA u dzieci i młodzieży chorej na AZS od 6. do 17. roku życia. U pacjentów ważących $60 \mathrm{~kg}$ lub więcej stosuje się schemat dawkowania jak $\mathrm{u}$ dorosłych. U pacjentów z masą ciała od $30 \mathrm{~kg}$ do $60 \mathrm{~kg}$ dawka początkowa wynosi $400 \mathrm{mg} \mathrm{w}$ dwóch wstrzyknięciach po $200 \mathrm{mg}$, a następnie $200 \mathrm{mg}$ co 2 tygodnie, podawane podskórnie. Pacjentom ważącym od $15 \mathrm{~kg}$ do $30 \mathrm{~kg}$ zaleca się dawkę początkową $600 \mathrm{mg}$ w dwóch wstrzyknięciach po 300 mg, a następnie $300 \mathrm{mg}$ co 4 tygodnie. U dzieci w wieku od 6 . miesiąca do 6 lat chorych na AZS trwa II i III faza badań klinicznych Liberty AD PRESCHOOL (NCT03346434).

\section{PODSUMOWANIE}

Podstawą leczenia AZS są emolienty, miejscowe GKS i IK w terapii proaktywnej. W przypadkach nieodpowiadających na standardowe leczenie miejscowe 
Currently, further monoclonal antibodies are being investigated: anti-IL-31 - nemolizumab, anti-IL-4, IL-13 - lebrikizumab, tralokinumab, anti-IL-22 fezakinumab, anti-TSLP - tezepelumab and JAK inhibitors: upadacitinib, tofacitinib [55-57]. However, despite promising preliminary research results, further work is needed before the therapeutic revolution in AD becomes a reality.

A close cooperation with the patient, education and psychological support are inseparable elements of the procedure.

\section{CONFLICT OF INTEREST}

The authors declare no conflict of interest. należy rozważyć dołączenie fototerapii i CsA. U pacjentów z ciężką postacią AZS, którzy nie reagują na leczenie miejscowe i u których leczenie ogólne nie jest wskazane, lekiem z wyboru jest dupilumab - pierwszy lek biologiczny zarejestrowany do leczenia AZS.

Leczenie biologiczne zajmuje coraz ważniejsze miejsce w skutecznej i nowoczesnej terapii AZS. Obecnie prowadzone są badania nad kolejnymi przeciwciałami monoklonalnymi, takimi jak anty-IL-31 - nemolizumab, anty-IL-4, IL-13 - lebrikizumab, tralokinumab, anty-IL-22 - fezakinumab, anty-TSLP - tezepelumab oraz inhibitorami JAK: upadacitinib, tofacitinib [55-57]. Pomimo obiecujących wstępnych wyników potrzebne są dalsze prace, zanim rewolucja terapeutyczna w AZS stanie się rzeczywistością.

Nieodłącznym elementem postępowania jest ścisła współpraca z pacjentem, edukacja, a także wsparcie psychologiczne.

\section{KONFLIKT INTERESÓW}

Autorzy nie zgłaszają konfliktu interesów.

\section{References}

\section{Piśmiennictwo}

1. Bieber T.: How to define atopic dermatitis? Dermatol Clin 2017, 35, 275-281.

2. Williams H., Flohr C.: How epidemiology has challenged 3 prevailing concepts about atopic dermatitis. J Allergy Clin Immunol 2006, 118, 209-213.

3. Odhiambo J.A., Williams H.C., Clayton T.O., Robertson C.F., Asher M.I.: Global variations in prevalence of eczema symptoms in children from ISAAC phase three. J Allergy Clin Immunol 2009, 124, 1251-8.e23.

4. Brunner P.M., Silverberg J.I., Guttman-Yassky E., Paller A.S., Kabashima K., Amagai M., et al.: Increasing comorbidities suggest that atopic dermatitis is a systemic disorder. J Invest Dermatol 2017, 137, 18-25.

5. Zhang A., Silverberg J.I.: Association of atopic dermatitis with being overweight and obese: a systematic review and metaanalysis. J Am Acad Dermatol 2015, 72, 606-616.e4.

6. Hjuler K.F., Bottcher M., Vestergaard C., Deleuran M., Raaby L., Botker H.E., et al.: Increased prevalence of coronary artery disease in severe psoriasis and severe atopic dermatitis. Am J Med 2015, 128, 1325-1334.e2.

7. Standl M., Tesch F., Baurecht H., Rodriguez E., Muller-Nurasyid M., Gieger C., et al.: Association of atopic dermatitis with cardiovascular risk factors and diseases. J Invest Dermatol 2017, 137, 1074-1081.

8. Legendre L., Barnetche T., Mazereeuw-Hautier J., Meyer N., Murrell D., Paul C.: Risk of lymphoma in patients with atopic dermatitis and the role of topical treatment:a systematic review and meta-analysis. J Am Acad Dermatol 2015, 72, 992-1002.

9. Farzanfar D., Dowlati Y., French L.E., Lowes M.A., Alavi A.: Inflammation: a contributor to depressive comorbidity in inflammatory skin disease. Skin Pharmacol Physiol 2018, 31, 246-251.

10. Thyssen J.P., Hamann C.R., Linneberg A., Dantoft T.M., Skov L., Gislason G.H., et al.: Atopic dermatitis is associated with anxiety, depression, and suicidal ideation, but not with psychiatric hospitalization or suicide. Allergy 2018, 73, 214-220.

11. Li J.C., Fishbein A., Singam V., Patel K.R., Zee P.C., Attarian H., et al.: Sleep disturbance and sleep-related impairment in adults with atopic dermatitis: a cross-sectional study. Dermatitis 2018, 29, 270-277.

12. Caroll C.L., Balkrishnan R., Feldman S.R., Fleischer Jr A.B., Manuel J.C.: The burden of atopic dermatitis: impact on the burden of atopic dermatitis: impact on the patient, family, and society. Pediatr Dermatol 2005, 22, 192-199.

13. Strom M.A., Fishbein A.B., Paller A.S., Silverberg J.I.: Association between atopic dermatitis and attention deficit hyperactivity disorder in U.S. children and adults. Br J Dermatol 2016, 175, 920-929.

14. Miyazaki C., Koyama M., Ota E., Swa T., Mlunde L.B., Amiya R.M., et al.: Allergic diseases in children with attention deficit hyperactivity disorder: a systematic review and meta-analysis. BMC Psychiatry 2017, 17, 120.

15. Yu S.H., Silverberg J.I.: Association between atopic dermatitis and depression in US adults. J Invest Dermatol 2015, 135, 3183-3186.

16. Simpson E.L., Guttman-Yassky E., Margolis D.J., Feldman S.R., Qureshi A., Hata T., et al.: Association of inadequately controlled disease and disease severity with patient-reported disease burden in adults with atopic dermatitis. JAMA Dermatol 2018, 154, 903-912. 
17. Williams H.C., Burney P.G., Hay R.J., Archer C.B., Shipley M.J., Hunter J.J., et al.: The U.K. working party's diagnostic criteria for atopic dermatitis. I. Derivation of a minimum set of discriminators for atopic dermatitis. Br J Dermatol 1994, 131, 383-396.

18. Eichenfield L.F., Tom W.L., Chamlin S.L., Feldman S.R., Hanifin J.M., Simpson E.L., et al.: Guidelines of care for the management of atopic dermatitis: section 1. Diagnosis and assessment of atopic dermatitis. J Am Acad Dermatol 2014, 70, $338-351$.

19. Schmitt J., Spuls P.I., Thomas K.S., Simpson E., Furue M., Deckert S., et al.: The Harmonising Outcome Measures for Eczema (HOME) statement to assess clinical signs of atopic eczema in trials. J Allergy Clin Immunol 2014, 134, 800-807.

20. Schmitt J., Langan S., Deckert S., Svensson A., von Kobyletzki L., Thomas K., et al.: Assessment of clinical signs of atopic dermatitis: a systematic review and recommendation. J Allergy Clin Immunol 2013, 132, 1337-1347.

21. Oranje A.P., Glazenburg E.J., Wolkerstorfer A., de Waard-van der Spek F.B.: Practical issues on interpretation of scoring atopic dermatitis: the SCORAD index, objective SCORAD and the three-item severity score. Br J Dermatol 2007, 157, 645-648.

22. Hanifin J.M., Thurston M., Omoto M., Cherill R., Tofte S.J., Graeber M.: The eczema area and severity index (EASI): assessment of reliability in atopic dermatitis. EASI Evaluator Group. Exp Dermatol 2001, 10, 11-18.

23. Leshem Y.A., Hajar T., Hanifin J.M., Simpson E.L.: What the Eczema Area and Severity Index score tells us about the severity of atopic dermatitis: an interpretability study. Br J Dermatol 2015, 172, 1353-1357.

24. Rullo V.E., Segato A., Kirsh A., Sole D.: Severity scoring of atopic dermatitis: a comparison of two scoring systems. Allergol Immunopathol 2008, 36, 205-211.

25. Futamura M., Leshem Y.A., Thomas K.S., Nankervis H., Williams H.C., Simpson E.L.: A systematic review of Investigator Global Assessment (IGA) in atopic dermatitis (AD) trials: many options, no standards. J Am Acad Dermatol 2016, 74, $288-294$.

26. Wollenberg A., Barbarot S., Bieber T., Christen-Zaech S., Deleuran M., Fink-Wagner A., et al.: Consensus-based European guidelines for treatment of atopic eczema (atopic dermatitis) in adults and children: part II. J Eur Acad Dermatol Venereol 2018, 32, 850-878.

27. Tiplica G.S., Boralevi F., Konno P., Malinauskiene L., Kaszuba A., Laurens C., et al.: The regular use of an emollient improves symptoms of atopic dermatitis in children: a randomized controlled study. J Eur Acad Dermatol Venereol 2018, 32, 1180-1187.

28. Grillo M., Gassner L., Marshman G., Dunn S., Hudson P.: Pediatric atopic eczema: the impact of an educational intervention. Pediatr Dermatol 2006, 23, 428-436.

29. Fostini A.C., Georgescu V., Decoster C.J., Girolomoni G.: A cream based on Aquaphilus dolomiae extracts alleviates non-histaminergic pruritus in humans. Eur J Dermatol 2017, 27, 317-318.

30. Gueniche A., Knaudt B., Schuck E., Volz T., Bastien P., Martin R., et al.: Effects of nonpathogenic Gram-negative bacterium Vitreoscilla filiformis lysate on atopic dermatitis: a prospective, randomized, double-blind, placebo-controlled clinical study. Br J Dermatol 2008, 159, 1357-1363.

31. Bianchi P., Theunis J., Casas C., Villeneuve C., Patrizi A., Phulpin C., et al.: Effects of a new emollient-based treatment on skin microflora balance and barrier function in children with mild atopic dermatitis. Pediatr Dermatol 2016, 33, 165-171.

32. Tiplica G.S., Kaszuba A., Malinauskiene L., Konno P., Boralevi F., Garrigue E., et al.: Prevention of flares in children with atopic dermatitis with regular use of an emollient containing glycerol and paraffin: a randomized controlled study. Pediatr Dermatol 2017, 34, 282-289

33. Gelmetti C., Wollenberg A.: Atopic dermatitis - all you can do from the outside. Br J Dermatol 2014, 170 Suppl, 19-24.

34. Gonzalez-Lopez G., Ceballos-Rodriguez R.M., Gonzalez-Lopez J.J., Feito Rodriguez M., Herranz-Pinto P.: Efficacy and safety of wet wrap therapy for patients with atopic dermatitis: a systematic review and meta-analysis. Br J Dermatol 2017, $177,688-695$

35. Wollenberg A., Ehmann L.M.: Long term treatment concepts and proactive therapy for atopic eczema. Ann Dermatol 2012, 24, 253-260.

36. Cury Martins J., Martins C., Aoki V., Gois A.F.T., Ishii H.A., da Silva E.M.K.: Topical tacrolimus for atopic dermatitis. Cochrane Database Syst Rev 2015, 7, CD009864.

37. Paller A.S., Tom W.L., Lebwohl M.G., Blumenthal R.L., Boguniewicz M., Call R.S., et al.: Efficacy and safety of crisaborole ointment, a novel, nonsteroidal phosphodiesterase 4 (PDE4) inhibitor for the topical treatment of atopic dermatitis (AD) in children and adults. J Am Acad Dermatol 2016, 75, 494-503.e6.

38. Dotterud L.K., Wilsgaard T., Vorland L.H., Falk E.S.: The effect of UVB radiation on skin microbiota in patients with atopic dermatitis and healthy controls. Int J Circumpolar Health 2008, 67, 254-260.

39. Schmitt J., Schmitt N., Meurer M.: Cyclosporin in the treatment of patients with atopic eczema - a systematic review and meta-analysis. J Eur Acad Dermatol Venereol 2007, 21, 606-619.

40. Harper J.I., Ahmed I., Barclay G., Lacour M., Hoeger P., Cork M.J., et al.: Cyclosporin for severe childhood atopic dermatitis: short course versus continuous therapy. Br J Dermatol 2000, 142, 52-58.

41. Simpson E.L., Bruin-Weller M., Flohr C., Ardern-Jones M.R., Barbarot S., Deleuran M., et al.: When does atopic dermatitis warrant systemic therapy? Recommendations from an expert panel of the International Eczema Council. J Am Acad Dermatol 2017, 77, 623-633.

42. Dias-Polak D., Bergman R., Avitan-Hersh E.: Mycophenolate mofetil therapy in adult patients with recalcitrant atopic dermatitis. J Dermatolog Treat 2019, 30, 49-51.

43. Simpson E.L., Bieber T., Guttman-Yassky E., Beck L.A., Blauvelt A., Cork M.J., et al.: Two phase 3 trials of dupilumab versus placebo in atopic dermatitis. N Engl J Med 2016, 375, 2335-2348.

44. Blauvelt A., de Bruin-Weller M., Gooderham M., Cather J.C., Weisman J., Pariser D., et al.: Long-term management of moderate-to-severe atopic dermatitis with dupilumab and concomitant topical corticosteroids (LIBERTY AD CHRONOS): a 1-year, randomised, double-blinded, placebo-controlled, phase 3 trial. Lancet 2017, 389, 2287-2303.

45. de Bruin-Weller M., Thaci D., Smith C.H., Reich K., Cork M.J., Radin A., et al.: Dupilumab with concomitant topical corticosteroid treatment in adults with atopic dermatitis with an inadequate response or intolerance to ciclosporin $\mathrm{A}$ or when this treatment is medically inadvisable: a placebo-controlled, randomized phase III clinical t. Br J Dermatol 2018, 178, $1083-1101$. 
46. Gooderham M.J., Hong H.C., Eshtiaghi P., Papp K.A.: Dupilumab: a review of its use in the treatment of atopic dermatitis. J Am Acad Dermatol 2018, 78 (3 Suppl 1), S28-S36.

47. Bao L., Zhang H., Chan L.S.: The involvement of the JAK-STAT signaling pathway in chronic inflammatory skin disease atopic dermatitis. JAKSTAT 2013, 2, e24137.

48. Wenzel S., Ford L., Pearlman D., Spector S., Sher L., Skobieranda F., et al.: Dupilumab in persistent asthma with elevated eosinophil levels. N Engl J Med 2013, 368, 2455-2466.

49. Beck L.A., Thaci D., Hamilton J.D., Graham N.M., Bieber T., Rocklin R., et al.: Dupilumab treatment in adults with moderate-to-severe atopic dermatitis. N Engl J Med 2014, 371, 130-139.

50. Ou Z., Chen C., Chen A., Yang Y., Zhou W.: Adverse events of dupilumab in adults with moderate-to-severe atopic dermatitis: a meta-analysis. Int Immunopharmacol 2018, 54, 303-310.

51. Wollenberg A., Ariens L., Thurau S., van Luijk C., Seegraber M., de Bruin-Weller M.: Conjunctivitis occurring in atopic dermatitis patients treated with dupilumab-clinical characteristics and treatment. J Allergy Clin Immunol Pract 2018, 6, 17781780.

52. Treister A.D., Kraff-Cooper C., Lio P.A.: Risk factors for dupilumab-associated conjunctivitis in patients with atopic dermatitis. JAMA Dermatol 2018, 154, 1208-1211.

53. Wang F.P., Tang X.J., Wei C.Q., Xu L.R., Mao H., Luo F.M.: Dupilumab treatment in moderate-to-severe atopic dermatitis: a systematic review and meta-analysis. J Dermatol Sci 2018, 90, 190-198.

54. Treister A.D., Lio P.A.: Long-term off-label dupilumab in pediatric atopic dermatitis: a case series. Pediatr Dermatol 2019, $36,85-88$.

55. Ruzicka T., Hanifin J.M., Furue M., Pulka G., Mlynarczyk I., Wollenberg A., et al.: Anti-interleukin-31 receptor a antibody for atopic dermatitis. N Engl J Med 2017, 376, 826-835.

56. Snast I., Reiter O., Hodak E., Friedland R., Mimouni D., Leshem Y.A.: Are biologics efficacious in atopic dermatitis? A systematic review and meta-analysis. Am J Clin Dermatol 2018, 19, 145-165.

57. Deleanu D., Nedelea I.: Biological therapies for atopic dermatitis: an update. Exp Ther Med 2019, 17, 1061-1067.

Received: 15.03 .2019

Accepted: 21.05 .2020

Otrzymano: $15.03 .2019 \mathrm{r}$.

Zaakceptowano: $21.05 .2020 \mathrm{r}$. 